\title{
Balzac, Gobseck
}

\section{Marco Stupazzoni}

\section{(2) OpenEdition}

\section{Journals}

\section{Edizione digitale}

URL: http://journals.openedition.org/studifrancesi/10668

DOI: 10.4000/studifrancesi. 10668

ISSN: 2427-5856

\section{Editore}

Rosenberg \& Sellier

\section{Edizione cartacea}

Data di pubblicazione: 1 décembre 2017

Paginazione: 564

ISSN: 0039-2944

\section{Notizia bibliografica digitale}

Marco Stupazzoni, «Balzac, Gobseck», Studi Francesi [Online], 183 (LXI | III) | 2017, online dal 01 février 2018, consultato il 30 janvier 2021. URL: http://journals.openedition.org/studifrancesi/10668 ; DOI: https://doi.org/10.4000/studifrancesi. 10668

Questo documento è stato generato automaticamente il 30 janvier 2021.

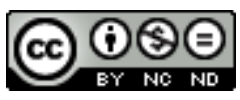

Studi Francesi è distribuita con Licenza Creative Commons Attribuzione - Non commerciale - Non opere derivate 4.0 Internazionale. 


\title{
Balzac, Gobseck
}

\author{
Marco Stupazzoni
}

\section{NOTIZIA}

HONORÉ DE BALZAC, Gobseck, traduzione e note di Maurizio Ferrara, Bagno a Ripoli (FI), Passigli Editori, 2016, «Le occasioni. Piccola Biblioteca Passigli», 111 pp.

1 Il primo frammento di quella che diventerà una delle più penetranti e incisive «scènes de la vie parisienne» è apparso, con il titolo di L'Usurier, ne «La Mode» del marzo 1830. Un mese più tardi, vede la luce, nelle Scènes de la vie privée, la prima edizione del racconto balzachiano pubblicato dagli editori Mame-Delaunay et Vallée con il titolo di: Les Dangers de l'inconduite. La presente traduzione italiana dell'opera di Balzac, curata anche nell'apparato delle note al testo da Maurizio Ferrara, si fonda sul modello dell'edizione originale (1830) e non su quello dell'edizione definitiva Furne del 1842 ( $\mathrm{La}$ Comédie humaine - Scènes de la vie parisienne, t. II). Viene mantenuta, infatti, la suddivisione del testo in tre capitoli preceduti da un Prologo ( «I pericoli della cattiva condotta»): questa ripartizione in capitoli sarà abolita da Balzac nell'edizione definitiva del 1842 , mentre di rilevanza minore risultano essere le varianti testuali di questa ultima versione rispetto al testo dell'edizione originale. 